\title{
Evaluation of Indoor Environmental Quality and Health Concerns in a Commercial Office Building Near a Helipad
}

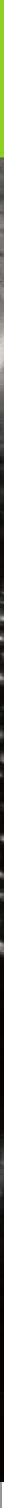

HHE Report No. 2015-0037-3283

June 2017

Leonard M. Zwack, ScD Christine A. West, PhD, RN, COHN-S Nancy C. Burton, PhD, MPH, MS, CIH Alberto Garcia, MS 


\section{Contents}

Highlights.

Abbreviations ...................................... iii

Introduction ................................... 1

Methods .............................................. 1

Results ............................................... 3

Discussion ........................................... 9

Conclusions....................................... 12

Recommendations.......................... 13

Appendix A ........................................ 16

References.......................................... 18

Acknowledgements............................ 23

The employer is required to post a copy of this report for 30 days at or near the workplace(s) of affected employees. The employer must take steps to ensure that the posted report is not altered, defaced, or covered by other material.

The cover photo is a close-up image of sorbent tubes, which are used by the HHE Program to measure airborne exposures. This photo is an artistic representation that may not be related to this Health Hazard Evaluation. Photo by NIOSH. 


\section{Highlights of this Evaluation}

The Health Hazard Evaluation Program received a request from employees working in a commercial office building. They were concerned about potential exposure to fuel and other chemical odors that were believed to be from a nearby helipad.

\section{What We Did}

- We evaluated the building in August 2015.

- We assessed the likely sources of fuel and other chemical odors, and pathways to enter the building.

- We looked at the design and operation of ventilation system and its air filtration system.

- We measured carbon dioxide, carbon monoxide, temperature, and relative humidity.

- We interviewed employees. We asked about their work, medical history, and work-related health concerns.

\section{What We Found}

- It is likely that the fuel odors are coming from outside the building.

- Existing conditions could allow for fuel odors to be drawn into the building. Helicopter exhaust from a nearby helipad is a likely source of fuel odors.

- Diesel emergency generators on the roof of the north building, nearby ferry terminals, and a large highway could also be sources of fuel odors.

- We did not smell fuel odors in the building during our 2 days onsite.

- We did not find any likely sources of fuel odors inside the building.

We evaluated indoor environmental quality in an office building. We found external sources of odors, including a heliport and nearby diesel generators. Most interviewed employees who reported health symptoms of sinus congestion and upper respiratory irritation reported symptoms occurred during times when fuel-like odors were present. We recommended a comprehensive ventilation assessment, testing generators only on weekends, and working with municipal authorities on ways to reduce helicopter traffic near the building.

- We noticed odors from personal fragrance use and cooking odors throughout the space.

- Employee symptoms of sinus congestion, headache, and eye, nose, and throat irritation have been associated with odors and poor indoor environmental quality.

- Eliminating external sources of the fuel exhaust, such as from helicopter exhaust, would likely reduce corresponding odor problems inside the building.

- The installed activated charcoal filters are ineffective in capturing and removing the fuel odors from the outdoor air. 
- The New York City Economic Development Corporation and the Helicopter Tourism and Jobs Council announced measures to reduce the impact of tourism helicopters on New York City residents by reducing the number of flights.

\section{What the Employer Can Do}

- Work with the New York City Economic Development Corporation and the heliport on ways to reduce helicopter traffic near the building.

- Complete a test and balance of the ventilation system that serves the employer spaces to verify that sufficient outdoor air is supplied.

- Test the emergency diesel generators only on weekends.

- Improve communication between the building owner, employer, union representatives, and employees regarding responses to employee safety and health concerns.

- Implement an indoor environmental quality management program.

- Relocate employees sensitive to the fuel odors to a different area of the building.

- Implement a fragrance-free policy.

- Encourage employees to report work-related concerns to the employer so steps can be taken to evaluate potential exposures.

\section{What Employees Can Do}

- Continue to report health and safety concerns to the employer.

- Seek evaluation from a healthcare provider if you have symptoms you think are related to work. 


\section{Abbreviations}

ACGIH® $\quad$ American Conference of Governmental Industrial Hygienists

AHU

Air handling unit

ANSI

American National Standards Institute

CFR

Code of Federal Regulations

$\mathrm{CO}_{2}$

Carbon dioxide

$\mathrm{CO}$

Carbon monoxide

EPA

Environmental Protection Agency

FPM

Feet per minute

HVAC

Heating, ventilation, and air-conditioning

IEQ

Indoor environmental quality

LEED

Leadership in Energy and Environmental Design

$\mathrm{NIOSH}$

National Institute for Occupational Safety and Health

NYCEDC

New York City Economic Development Corporation

OEL

Occupational exposure limit

OSHA

Occupational Safety and Health Administration

PESH

Public Employee Safety and Health

ppm

Parts per million

$\mathrm{RH}$

Relative humidity

STEL

Short-term exposure limit

TLV®

Threshold limit value

TWA

Time-weighted average

VOC

Volatile organic compound 
This page left intentionally blank 


\section{Introduction}

The Health Hazard Evaluation Program received a request from employees working in a large commercial office building regarding potential exposure to fuel and other chemical odors. The employees stated that they believed the odors were coming from a large commercial helipad located across from the building. During our August 2015 site visit we met with employees, managers, and union representatives. We also examined the occupied space and interviewed employees about their work and health.

\section{Background}

The employer was a government agency that occupied part of a large commercial office building in New York City. The building was located near a commercial helipad, two large ferry terminals, and a major highway. The employer reported that they had received employee complaints about fuel or chemical odors since moving into the building in 2009. Since 2012, over 300 odor incidents had been documented. The incidents included employee symptoms such as respiratory tract irritation, burning eyes and skin, headaches, and increased asthma symptoms. These odor incidents lasted anywhere from a few seconds up to about 30 minutes, and the interval between incidents could be weeks or months. Most employees and employer representatives we spoke with attributed the odors to flights from the nearby helipad. The government agency and the building owners had hired consultants to evaluate the building indoor environmental quality (IEQ), and the New York Public Employee Safety and Health Bureau (PESH) had conducted site visits to assess exposures. During Hurricane Sandy, in the fall of 2012, the lower floors of the building were completely filled with water and the building was closed for many weeks. Upon reoccupying the building, employees reported additional odors.

The government agency that was the focus of this evaluation had 1,143 employees and occupied space on floors 4 through 9 , as well as on the concourse and the subfloors. Other tenants in the building were not included in this assessment. Each floor had 60,000 square feet, about 48,000 of which were occupied. The space was generally occupied by employees between 7 a.m. and 5 p.m., Monday through Friday, though some employees worked outside of these hours.

\section{Methods}

Our objectives for this evaluation were:

1. To assess the source of transient fuel or other chemical odors entering the building.

2. To assess the effectiveness of the ventilation system in the building.

3. To determine whether employees were having symptoms consistent with fuel and other chemical odor exposures.

\section{Indoor Environmental Quality Consultant Reports}

We reviewed the IEQ-related consultant reports provided to us by the employer and the building owners. Five reports were provided to us for IEQ assessments conducted between 2012 and 2014. 


\section{Building Walk-through Survey}

We toured all of the spaces occupied by the employer in the building. This included floors 4 through 9, as well as the concourse and lower level. We also toured the 2 nd and 14th floors, which contained the air handling units (AHUs) and the air intakes serving the employer occupied space.

We measured temperature and relative humidity $(\mathrm{RH})$ at nine locations across floors 4 through 9 using $\mathrm{HOBO}{ }^{\circledR} \mathrm{H} 8$ ProSeries data loggers. These instruments were placed on employee desks in empty cubicles or on tables, and we measured from 12:30 p.m. to 6 p.m. on day 1, and from 6 a.m. to 4 p.m. on day 2. We compared the temperature and RH levels to American National Standards Institute (ANSI)/ASHRAE thermal comfort guidelines for summer [ANSI/ASHRAE 2013]. The ANSI/ASHRAE Standard 55-2013, Thermal Environmental Conditions for Human Occupancy, specifies conditions in which $80 \%$ or more of the occupants would be expected to find the environment thermally comfortable [ANSI/ ASHRAE 2013]. Several factors affect thermal comfort including air movement, operative temperature, $\mathrm{RH}$, clothing levels, and an individual's work activities. A thermal comfort tool developed by the Center for the Built Environment allows comparison to the ANSI/ASHRAE criteria and is available at http://comfort.cbe.berkeley.edu/. The U.S. Environmental Protection Agency (EPA) recommends that RH be maintained below 60\% (ideally between $30 \%-50 \%$ ) to prevent mold growth. Very low RH levels may contribute to dry and irritated mucous membranes of the eyes and airways [Wolkoff and Kjaergaard 2007].

We measured for carbon monoxide (CO) using a direct-reading BW Technologies GasAlert ${ }^{\circledR}$ Extreme meter at the same locations where we took temperature and $\mathrm{RH}$ measurements. $\mathrm{CO}$ measurement results indicate whether combustion gases are entering a building. We selected the sampling locations to ensure that we covered a spatially diverse area across the various floors. For the 5 th and 6 th floors, we monitored in multiple locations because we were told that most complaints came from these two floors.

We measured instantaneous carbon dioxide $\left(\mathrm{CO}_{2}\right)$ concentrations at 15 locations across floors 4 through 9 using a calibrated TSI Q-Trak ${ }^{\text {TM }}$ Indoor Air Quality Monitor. We compared indoor and outdoor $\mathrm{CO}_{2}$ concentrations to determine if indoor occupied spaces were adequately ventilated [ANSI/ASHRAE 2016]. $\mathrm{CO}_{2}$ is a normal constituent of exhaled breath and can be used as an indicator of whether enough outdoor air is being introduced into an occupied space to maintain odors to an acceptable level. Indoor $\mathrm{CO}_{2}$ concentrations no greater than 700 parts per million (ppm) above outdoor $\mathrm{CO}_{2}$ concentrations will satisfy a substantial majority (about 80\%) of visitors [ANSI/ASHRAE 2016].

We also reviewed the layout of the facility and a partial set of blueprints and supporting documents. These resources provided information regarding the design and operation of the heating, ventilation, and air-conditioning (HVAC) system and placement of supply and exhaust fans. We visually inspected the exterior and interior of multiple peripheral fan-coil units on the floors. We checked if the units were operational, the type and condition of the air filters, and if furniture or office supplies interfered with the flow of air through the unit. We visually inspected AHUs on the 2nd floor and three of the four AHUs on the 14th floor that supply air to the employer occupied space. We looked to see if they were operational, and 
if any potential odor sources were located nearby. We also examined the filters installed on the AHUs. Finally, we checked the airflow of 15 different supply air registers across floors 4 through 9 using a TSI Velocicalc ${ }^{\circledR}$ Plus Air Velocity Meter hot-wire anemometer.

\section{Employee Interviews and Medical Record Review}

We interviewed a convenience sample of employees, selected based on their office location, about their work history, acute and chronic health symptoms and conditions, smoking history, building thermal comfort, and satisfaction with workplace health and safety training. We also reviewed the New York Department of Labor/PESH SH 900 Log of Work-Related Injuries and Illnesses from 2012-2015.

\section{Results}

\section{Environmental Assessment}

\section{Building Walk-through Survey}

We did not notice fuel odors during our 2 days onsite. We did not find any likely sources of fuel odors inside the building. We noticed odors from personal fragrance use and cooking odors in many areas. The tenant did not have a fragrance-free policy in the office.

Floors 4 through 9 contained fan-coil units located around much of the perimeter of the occupied space. We saw many locations where the airflow into or out of these units was partially or completely blocked by furniture, equipment, boxes, and other objects (Figure 1). Blocking air intakes and supply vents prevented the ventilation system from working as designed. We also saw laser printers near the peripheral fan-coil units. Particulates generated by the printers could easily be pulled into the air intakes of the fan-coil units and then be redistributed throughout the space (Figure 2). We inspected the metal-mesh filters in several of the fan coil units. These filters appeared to be in good condition; however, these low efficiency air filters were not designed to remove small particulates. 


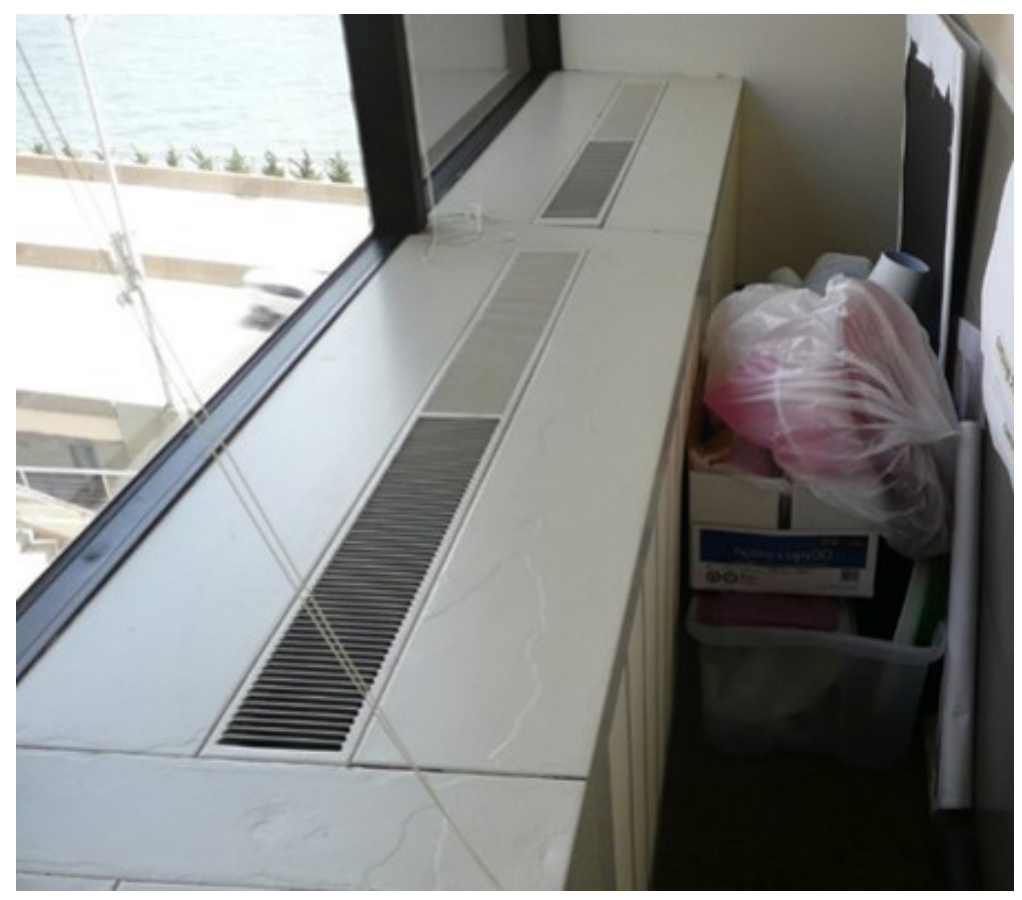

Figure 1. Office supplies and boxes blocking the air intake of a peripheral fan-coil unit. Photo by NIOSH.

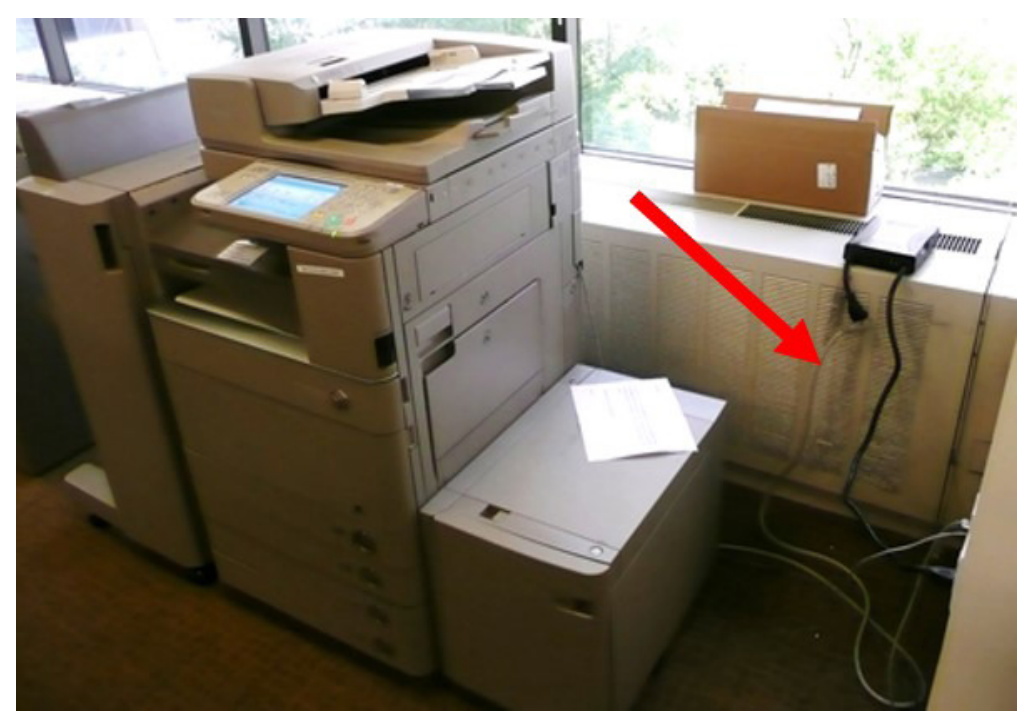

Figure 2. A laser printer located next to the air intake of the nearby peripheral fan-coil unit. The arrow points to a section of the air intake that is likely discolored by the printer's emissions. Photo by NIOSH. 


\section{Potential External Air Contaminant Sources}

One likely external source of fuel or chemical odors was from heliport and barge enterprises on the east side of the building. The heliport was about 84,000 square feet in size and reportedly could accommodate 12 helicopters at a time [Saker Aviation Services 2016]. Occasionally, flight patterns had helicopters flying close to the building's outdoor air intakes on the 14th floor. In 2014 the New York City Economic Development Corporation (NYCEDC) estimated that around 58,000 flights took off from the heliport, including over 56,000 tourist flights [Benepe and Birnbaum 2016]. Considering that the heliport operated daily between 7 a.m. and 10 p.m. this air traffic level equated to one helicopter taking off or landing every 6 minutes, on average. However, the building tenants reported that take-off and landing rates were higher during the early spring to late fall tourist season and this resulted in an increase in odor complaints. Agency managers also reported that complaints increased when the wind blew toward the building from the nearby river.

Other nearby sources of fuel and chemical odors included two public ferry terminals, a private ferry terminal, a multilane highway, street-level bus parking, and idling vehicles. The building owner reported that when outdoor temperatures were mild the HVAC system brought more outdoor air into the building, increasing the chance for helicopter, ferry, bus, or highway vehicle exhaust to enter the building.

Building managers reported to us that six emergency diesel generators were located on the roof of an adjacent 15-floor building (the north building) and eight were located on the roof of the building impacted by the odors (the south building). Building managers stated that these generators were tested monthly for 1 hour, usually on weekends but occasionally during the week. There was an agreement with the local energy company to take the north building off the power grid during periods of peak energy usage. Building managers reported this had occurred a few times, and when it did the emergency diesel generators ran for 6 to 8 hours. Depending on prevailing wind direction, exhaust from the generators on the roof of the north building could be pulled into the air intakes of the south office building.

\section{Previous Indoor Environmental Quality Reports}

The six IEQ-related consultant reports we reviewed are summarized in Table 1. None of the three PESH reports noted fuel odors or measured indoor air contaminant concentrations above occupational exposure limits (OELs). An assessment in 2012 concluded that employees' symptoms were likely associated with exhaust from the heliport and/or ferry terminals. An assessment in August 2013 found that indoor volatile organic compound (VOC) concentrations were above the Leadership in Energy and Environmental Design (LEED) standard limits. It should be noted that these are not regulatory or health-based exposure limits. The consultant also found a potential refrigerant leak from the HVAC system; measured levels of the refrigerant, bromotrifluoromethane (R1301), were above the instrument manufacturer's leak detection level. This report did not state if fuel odors were detected during the consultant's time onsite. A follow-up report described an evaluation of the efficacy of an AtmosAir 500F air purification system that had been installed at four locations on the 5 th floor. The report noted that the purification system was not having a measurable effect on pollutant concentrations. Supply air intakes on floors 4,5 , and 7 were reported as nonoperational. 
Table 1. Summary of environmental assessments in the building

\begin{tabular}{|c|c|c|c|c|}
\hline Report date & Source & Activities & Methods & Findings \\
\hline $4 / 2012$ & $\begin{array}{l}\text { Industrial } \\
\text { hygiene } \\
\text { consulting } \\
\text { firm \#1 }\end{array}$ & $\begin{array}{l}\text { IEQ assessment } \\
\text { of the } 4 \text { th and } \\
5 \text { th floors and } \\
\text { heliport }\end{array}$ & $\begin{array}{l}\text { Collected evacuated } \\
\text { canisters and used } \\
\text { real-time monitors } \\
\text { for VOCs during an } \\
\text { odor incident }\end{array}$ & $\begin{array}{l}\text { Indoor VOCs levels did not } \\
\text { trigger regulatory concerns. } \\
\text { Symptoms likely } \\
\text { associated with the heliport } \\
\text { and/or ferry terminals. }\end{array}$ \\
\hline $8 / 1 / 2012$ & PESH & $\begin{array}{l}\text { Bed bug } \\
\text { inspection on } \\
\text { 6th-8th floors }\end{array}$ & $\begin{array}{l}\text { Visual assessment } \\
\text { for bed bugs }\end{array}$ & $\begin{array}{c}\text { No bed bugs were } \\
\text { observed. Complaint from } \\
\text { employee about possible } \\
\text { exposure to extermination } \\
\text { chemicals. Recommended } \\
\text { assessment by an } \\
\text { industrial hygienist. }\end{array}$ \\
\hline 9/14/2012 & PESH & $\begin{array}{l}\text { IEQ assessment } \\
\text { of the } 5 \text { th floor }\end{array}$ & $\begin{array}{l}\text { Collected air } \\
\text { samples for } \\
12 \text { gases }\end{array}$ & $\begin{array}{l}\text { No fuel odor was observed. } \\
\text { Gases were not present } \\
\text { above the detection limit. }\end{array}$ \\
\hline $8 / 22 / 2013$ & $\begin{array}{l}\text { Industrial } \\
\text { hygiene } \\
\text { consulting } \\
\text { firm \#2 }\end{array}$ & $\begin{array}{l}\text { IEQ assessment } \\
\text { of the } 4 \text { th and } \\
5 \text { th floors }\end{array}$ & $\begin{array}{c}\text { Measured } \\
\text { temperature, } \mathrm{RH}, \\
\mathrm{CO}_{2}, \mathrm{CO}, \\
\text { nitrogen dioxide, } \\
\text { sulfur dioxide, VOCs } \\
\text { and collected } \\
\text { fungal samples }\end{array}$ & $\begin{array}{l}\text { Total VOCs detected } \\
\text { above LEED standards and } \\
\text { refrigerant compounds } \\
\text { found above } \\
\text { manufacturer's leak } \\
\text { detection level. }\end{array}$ \\
\hline $11 / 15 / 2013$ & $\begin{array}{l}\text { Industrial } \\
\text { hygiene } \\
\text { consulting } \\
\text { firm \#2 }\end{array}$ & $\begin{array}{l}\text { Follow-up IEQ } \\
\text { assessment on } \\
\text { 4th, 5th, and } \\
\text { 7th floors }\end{array}$ & $\begin{array}{l}\text { Measured } \\
\text { temperature, } \mathrm{RH}, \\
\mathrm{CO}_{2}, \mathrm{CO}, \\
\text { nitrogen dioxide, } \\
\text { sulfur dioxide, } \\
\text { VOCs and } \\
\text { total particulate }\end{array}$ & $\begin{array}{l}\text { Most pollutants were found } \\
\text { at similar or lower } \\
\text { concentrations as previous } \\
\text { study. Found some } \\
\text { non-functional } \\
\text { supply air banks. }\end{array}$ \\
\hline $6 / 10 / 2014$ & PESH & $\begin{array}{l}\text { IEQ assessment } \\
\text { of the 5th floor }\end{array}$ & $\begin{array}{c}\text { Collected air } \\
\text { samples for } \\
\text { nitrogen dioxide, } \\
\text { sulfur dioxide, and } \\
\text { hydrocarbons }\end{array}$ & $\begin{array}{l}\text { No fuel odor was observed. } \\
\text { Gases were not present } \\
\text { above the detection limit. }\end{array}$ \\
\hline
\end{tabular}

\section{Carbon Monoxide, Carbon Dioxide, Temperature, and Relative Humidity}

Table 2 summarizes the temperatures and RH levels measured on floors 4 through 9 during occupied hours over 2 days of sampling. No CO was detected; the limit of detection was $1 \mathrm{ppm}$. Temperatures in most areas were similar to each other. The temperature in the northwest corner of the 6th floor was slightly lower than that on other floors, and the 6th floor was the only location with measured temperatures below $70^{\circ} \mathrm{F}$. On the basis of these measurements the offices were not within the recommended thermal comfort guidelines, assuming a metabolic rate for the occupants of 1.1 (equivalent to typing) and occupants wearing typical summer clothing [ANSI/ASHRAE 2013]. The temperatures in all of the spaces that we monitored were below the recommended thermal comfort guidelines for the summer season (Table 2). The RH levels were within the recommended range as all levels were below $60 \%$, and most were in the ideal range of $30 \%-50 \%$. 
Table 2. Temperature and relative humidity measurements in the space during occupied hours

\begin{tabular}{lccc}
\hline Date & Location & $\begin{array}{c}\text { Temperature }{ }^{\circ} \mathrm{F} \\
\text { (range) }\end{array}$ & $\begin{array}{c}\% \mathrm{RH} \\
\text { (range) }\end{array}$ \\
\hline Day 1 & 4th floor, cube 437F & $73-76^{*}$ & $43-46$ \\
(Sampling times: & 5th floor, cube 531C & $73-75^{*}$ & $42-44$ \\
12:30 p.m. to 6 p.m.) & 5th floor, cube 516D & $73-77^{*}$ & $46-56$ \\
& 5th floor, cube 504A & $74-75^{*}$ & $42-44$ \\
& 6th floor, filing cabinet, NW corner & $70-72^{*}$ & $42-50$ \\
6th floor, near column 63 & $74-79^{*}$ & $36-43$ \\
7th floor, cube 732D & $72-75^{*}$ & $44-45$ \\
8th floor, cube 812H & $74-74^{*}$ & $43-45$ \\
(Sampling times: & 9th floor, cube 931G & $74-75^{*}$ & $43-45$ \\
\hline a.m. to 4 p.m.) & 4th floor, cube 437F & $72-74^{*}$ & $47-50$ \\
& 5th floor, cube 531C & $72-75^{*}$ & $43-45$ \\
5th floor, cube 516D & $72-73^{*}$ & $51-57$ \\
5th floor, cube 504A & $73-75^{*}$ & $43-47$ \\
& 6th floor, filing cabinet, NW corner & $68-70^{*}$ & $51-55$ \\
6th floor, near column 63 & $70-77^{*}$ & $39-47$ \\
7th floor, cube 732D & $70-75^{*}$ & $45-50$ \\
8th floor, cube 812H & $73-77^{*}$ & $38-48$ \\
9th floor, cube 931G & $73-75^{*}$ & $41-47$ \\
\hline
\end{tabular}

*Temperatures were not within recommended thermal comfort guidelines [ANSI/ASHRAE 2013].

Instantaneous $\mathrm{CO}_{2}$ measurements taken on day 2 are presented in Table $3 . \mathrm{No} \mathrm{CO}_{2}$ concentrations were more than $700 \mathrm{ppm}$ above outdoor concentrations ( 350 to $400 \mathrm{ppm}$ ), indicating that adequate outdoor air was being supplied by the HVAC system to dilute body odors [ANSI/ASHRAE 2016].

Table 3. Carbon dioxide measurements in the building on day $2^{*}$

\begin{tabular}{lcc}
\hline Floor & Location & $\mathrm{CO}_{2}(\mathrm{ppm})$ \\
\hline 4 & Table near cube 422 & 610 \\
4 & Cube 437E & 510 \\
5 & Cube 516D & 560 \\
5 & Cube 531C & 540 \\
5 & Cube 504A & 580 \\
6 & Near pillar 63+64 & 530 \\
6 & Near pillar 1 & 560 \\
7 & Cube 732D & 550 \\
7 & Near 07.12 IT & 530 \\
8 & Small conference room & 730 \\
8 & Cube 812H & 520 \\
8 & Window near cube 811 & 620 \\
8 & Cube 836B & 620 \\
9 & Cube 931B & 480 \\
9 & Cube 921F & 470 \\
\hline${ }^{*} \mathrm{CO}_{2}$ concentrations are typically 350-400 ppm outdoors.
\end{tabular}




\section{Ventilation Systems}

The building HVAC system had multiple AHUs that provided conditioned air to the rooms via overhead variable air volume supply units. Information provided to us by the building owner stated that the employer occupied office space on floors 4 through 9 was served by four AHUs on the 14th floor. The outdoor air intake for each unit was located near the individual AHUs. All the observed AHU intakes used Viskon-Aire AS Series synthetic media multi-pocket air filters. The filtration system of AHUs S-10 and S-11 also used Carbonweb 300 charcoal filters in front of the regular particulate filters to remove VOCs from the air stream. When charcoal filtration is added to a general ventilation system, the charcoal bed filters are normally installed behind the particulate filters to extend the life of the charcoal filters. Table 4 identifies the air intake locations and zones served by each of the four AHUs.

Table 4. List of air handling units and the zones they serve

\begin{tabular}{lcc}
\hline Air handling unit & Floors served & Building section \\
\hline S-10 & Floors 3-13 & East \\
S-11 & Floors 3-13 & West \\
S-12 (perimeter) & Floors 4-13, 16-33 & South and east \\
S-14 (perimeter) & Floors 4-13, 16-33 & North and west \\
\hline
\end{tabular}

The building management and the employer had completed three initiatives over the previous 2 years to improve IEQ in the offices. These included activated carbon filtration of the outdoor air using granular media charcoal bed filters, which had been in use for 2 years; recirculating ionization units, which had also been in use for 2 years; and full sealing of the ductwork. We checked 15 supply air registers across floors 4 through 9 . We found positive airflow into the workspace at all 15 locations.

\section{Medical Assessment}

\section{Employee Interviews and Record Review}

We interviewed 46 of 1,143 employees; 33 worked on the 5th floor, and 13 worked on other floors, including the concourse, 4th, 6th, and 8th floors.

Of the 46 employees we interviewed, $62 \%$ were women. The average age of those interviewed was 54 years (range: 26-73 years). The average duration of employment was 21 years (range: 2-38 years). Thirty-four employees (74\%) reported respiratory symptoms that were worse at work. The most common upper respiratory symptoms reported were sinus congestion and eye, nose, and throat irritation; common lower respiratory symptoms were chest tightness and chronic cough. Three employees reported having asthma that they attributed to the workplace. Other common symptoms that improved on days off work were headaches, dizziness, nausea, and fatigue. Seventeen employees (37\%) reported having a history of respiratory problems such as allergic rhinitis/hay fever, asthma, emphysema, or other lung problems. Four employees (9\%) reported being current smokers. Forty-one employees $(89 \%)$ reporting smelling strong unpleasant odors in the building, and most who 
reported adverse symptoms did so near the time of smelling these odors. Most described the odors as a "fuel, chemical, exhaust, or fume smell" and reported the presence of the odor as moderate in frequency.

Regarding comfort issues, most employees we interviewed reported air temperatures being too cold and lighting to be inadequate. Thirty-nine employees (85\%) interviewed reported submitting a complaint about a health and safety concern to the employer and among them, 29 of the 39 (74\%) reported being "somewhat or very dissatisfied" with how it was addressed. Over half the employees (54\%) reported they felt supported by their immediate managers or supervisors; however, $40 \%$ of employees reported not feeling supported by upper level management and facilities personnel when they had a health and safety concern. Over half of the employees (55\%) reported a lack of open communication about health and safety concerns and stated they were not consulted about workplace health and safety issues.

The PESH SH900 logs for 2012-2015 had a total of 91 injury and illness entries; 56 of these entries were related to fume smells. Most of the reports were from employees working on the 5th floor, but some in 2012 were also from employees on the 4th floor. More entries involving fume smells were recorded in 2012 (36), compared to other years: 2013 (17), 2014 (2), and 2015 (1). Multiple entries were made by individual employees in 2012 and 2013. The most common health symptoms reported were headache and respiratory irritation. We also reviewed a log of health and safety complaints sent by employees to the employer related to indoor air quality concerns from 2012 to 2015. Employees commonly reported that unpleasant odors led to their health symptoms (upper and lower respiratory symptoms, headache, nausea, and dizziness).

\section{Discussion}

The intermittent nature of odor reports and complaints among tenant staff represents a challenge when addressing IEQ issues in office spaces. In addition, the building is located in an area where many local sources of external exhaust could enter the building through outdoor air intakes and affect building occupants. During our assessment, we did not notice fuel odors or find any plausible internal sources for odors described as "fuel or fume smells" inside the building. Therefore, external pollutants entering the building through the HVAC system outdoor air intakes are the likely source of the intermittent fuel odors. The building did have indoor odor sources including personal fragrances and cooking odors.

During our conversations with the building owner, employer, employees, and union representatives, most identified the helicopters as the likely source of odors. Under certain wind speeds and directions, because the building is close to the helipad, it is possible that helicopter exhaust is reaching the building's outdoor air intakes. Because of the short duration and transient nature of the fuel odors in the building, we did not conduct air monitoring for contaminants likely to cause these odors. Air monitoring done previously by a private consultant found low levels of VOCs. Although the concentrations were well below OELs, the consultant reported that employee symptoms could be related to fuel exhaust and accompanying odors, such as from helicopters. Eliminating external sources of the fuel exhaust, such as from helicopter exhaust, would likely reduce corresponding odor 
problems inside the building. In February 2016, the NYCEDC and the Helicopter Tourism and Jobs Council announced measures to reduce the impact of tourism helicopters on New York City residents [NYCEDC 2016]. The agreement called for a 50\% reduction in flights by January 2017. In addition the agreement stated that an air monitoring system near the heliport would be established, that helicopter operators would limit idling between flights, and that they would investigate available technologies to reduce emissions and implement them once commercially feasible. These changes may help to decrease the fuel odor events inside of the building. The feasibility of altering helicopter flight paths when the wind is blowing toward the building should also be investigated.

The rooftop emergency diesel generators on top of the north building could also be a source of odors indoors, because the generators are located relatively close to the south building air intakes. When the wind is blowing from north to south, it is possible that emissions from the generators could reach the air intakes of the south building. The diesel generators are on the roof of the 15th floor of the north building, while the air intakes are on the 14th floor of the south building. Conducting monthly test runs of the generators solely on weekends would decrease potential impact on the south building during heavily occupied times. As the generators can also be active during peak energy load times, it would be useful to try to match reports of odor complaints to periods of generator usage.

Other potential sources of fuel odors include exhaust from nearby ferry terminals, a multilane highway, and idling trucks and buses on surface streets. Under certain wind speeds and directions, it is possible that exhaust from these sources may be reaching the outdoor air intakes of the building.

In terms of potential ventilation controls for reducing odors, the added granular media charcoal bed filters use the principle of adsorption to remove chemicals from the air stream. Adsorption is a separation process based on the ability of certain solids to remove gaseous (or liquid) components preferentially from a flow stream. Physical adsorption is usually directly proportional to the amount of solid surface available. It is well known and documented that charcoal (activated carbon, like the filtration installed in units S-10 and S-11) has an affinity for hydrocarbons [Wark and Warner 1981]. One general requirement for the design or selection of suitable adsorption equipment is sufficient dwell time for interaction between the hydrocarboncontaminated air and the activated carbon adsorption media. In general, air velocities at the face of the bed are recommended to be from 20 to 100 feet per minute (fpm) with dwell times within the bed from 0.6 to 6 seconds [Wark and Warner 1981]. The existing charcoal filters are unlikely to effectively remove VOCs. The lack of sufficient filter material means there is not enough dwell time for proper contaminant removal. To provide enough dwell time with the existing filter selection, we estimate that air intake velocities should range from 0.8 to $8 \mathrm{fpm}$, which is not realistic for any HVAC system design. Most HVAC systems are designed for air intake velocities at the filter bank around $500 \mathrm{fpm}$. At a velocity of 500 feet per minute, we estimate that between 5 and 50 feet of charcoal filter would be needed to provide a sufficient dwell time for interaction between the hydrocarbon-contaminated air and the adsorption media. This amount of filtration is unrealistic for typical HVAC systems. Additionally, filtration is problematic as filters can become saturated and are often not changed frequently enough. Therefore, filtration is likely to not be effective in removing VOCs that enter the building from the outdoors. 
ANSI/ASHRAE Standard 62.1-2016, Ventilation for Acceptable Indoor Air Quality provides guidance on the minimum ventilation rates and outdoor air requirements for office buildings. In locations with highly polluted outdoor air, health risks from indoor air and outdoor air exposures need to be considered when maintaining ventilation rates [Sundell et al. 2011]. ANSI/ASHRAE provides recommendations for minimum separation distances for outdoor air intakes and potential sources of contamination. The standard states that outdoor air intakes "shall be located such that the shortest distance from the intake to any specific potential outdoor contaminant source shall be equal to or greater than the separation distance listed in Table 5.5.1" of the standard. There are no recommendations for air intake separation distances from helipads. However, Table 5.5.1 states that a minimum distance of 15 feet is required from garage entries, automobile loading areas, or drive-in queues and 25 feet is required from truck loading areas or docks and bus parking or idling areas [ANSI/ASHRAE 2016]. We did not observe any of these structures within 15 to 25 feet of the building's air intakes.

Odors from external and internal source pollutants during work hours are a likely contributor to symptoms reported by employees. In persons with existing health conditions, such as asthma or chronic respiratory problems, odors can worsen pre-existing symptoms. Odors have been found to trigger airway inflammation for at least 24 hours in asthmatics. Evidence also exists that odors caused by air pollutants can have psychological and central nervous system effects such as anxiety and panic attacks [Beach et al. 1997; Jaén and Dalton 2014; Shusterman 2002]. In hospital settings, helicopter exhaust fumes can enter building ventilation systems at levels above odor thresholds [Petersen et al. 1990]. A review of the literature published in 2010 determined that there is sufficient evidence of a causal association between exposure to traffic-related air pollution and worsening of asthma symptoms and suggestive evidence of a causal association for onset of non-asthma respiratory symptoms and impaired lung function [HEI 2010].

Indoor pollutants, such as VOCs, dust, and other allergens can be contributing to symptoms. We saw accumulations of dust near air intakes of the peripheral fan-coil units that may have contributed to the respiratory symptoms reported by some of the employees. VOCs are a large class of organic chemicals (i.e., containing carbon) that have a sufficiently high vapor pressure to allow some of the compounds to exist in the gaseous state at room temperature. It is widely recognized that airborne concentrations of many VOCs in office buildings are higher than concentrations in outdoor air because of numerous indoor sources of VOCs, and because the relatively low rates of outdoor air ventilation typically used in offices prevent the rapid dispersal of airborne contaminants [Daisey et al. 1994; Tucker 2000]. Consumer products used in offices (such as cleaners, air fresheners, and insect repellents) contain and emit VOCs as do materials and products used in new construction, remodeling, and redecorating [Hodgson and Levin 2003]. Studies have attributed symptoms to low levels of chemicals from office furnishings, office machines, cleaning products, personal hygiene products, and the building's structural components [EPA 2012]. Upper respiratory and mucous membrane irritation (including the eyes, nose, and throat) and headache are the most frequently reported symptoms in office buildings with VOC exposures [Apte and Daisey 1999]. We observed no visible mold or water intrusion in the building. Symptom complaints were higher in 2013, which may have been related to ongoing renovation that occurred to the 
building as a result of flooding from Hurricane Sandy in October 2012. Remediation of mold growth in homes and buildings was a significant challenge after the hurricane [Manual 2013]. Indoor exposure to damp buildings and molds has been linked to respiratory tract symptoms, cough, and wheeze in otherwise healthy individuals and to exacerbation of asthma symptoms in persons allergic to mold [WHO 2009].

Complaints of being too hot or too cold have been associated with headaches [Tietjen et al. 2012]. Whether occupants are comfortable with the office temperature depends on a number of factors, such as activity level while on the job, age, and personal body characteristics. To keep most people comfortable most of the time, ASHRAE specifies conditions in which $80 \%$ or more of the occupants would be expected to find the environment thermally comfortable. When the air is too warm, occupants may complain that the air is "stale" or "stuffy." Often times this leads occupants to think that the building air may somehow be contaminated, causing a perceived health risk. Whether too warm or too cold, occupants are likely to feel physical stress, which can make them less tolerant of other building discomforts. Studies show that even slight fluctuations in temperature or RH can reduce workers' ability to concentrate and perform mental or physical tasks [EPA 2017]. Poor lighting or glare, especially on computer screens, can cause eye strain, aching muscles, eye fatigue, and headache.

Employees reported a perceived lack of response and acknowledgement of concerns on health and safety matters. Some employees also reported limited opportunities to provide input on health and safety matters. Through workplace investigations, National Institute for Occupational Safety and Health (NIOSH) investigators have found that reduced job satisfaction and poor communication are common where IEQ complaints occur. These issues may be related to personnel organizational factors, conflict among personnel, or lack of job security. Providing feedback, involving employees in decision making, and allowing employees to provide input to the employer is associated with greater job satisfaction and positive perceptions of work [Kain and Jex 2010]. An individual's health can be affected by a perceived lack of response to odorous chemical exposure related to air quality, especially if the individual believes that the exposure is hazardous and has negative attitudes toward the exposure [Claeson et al. 2013].

\section{Conclusions}

On the basis of our employee interviews, observations, and document reviews, it appears that transient odors from nearby external sources such as a heliport, ferry terminals, emergency power generators, and a highway are likely entering the building's outdoor air intakes and resulting in periodic fuel odor complaints, and could be contributing to employees' symptoms. Helicopters are likely the predominant source of transient odors due to the proximity of the heliport to the building's outdoor air intakes. The current use of activated charcoal filters is ineffective in capturing and removing odors from outdoor air. Ventilation controls, such as filtration, are unlikely to eliminate the problem. Strategies to reduce the fuel odors include removing or reducing the sources of the external exhaust. Although we interviewed a small percentage of the total workforce, most who reported symptoms associated them with transient odors. This finding is consistent with previous IEQ evaluations and employee incident reports. 


\section{Recommendations}

On the basis of our findings, we recommend the actions listed below. We encourage the building management and the tenant to use a labor-management health and safety committee or working group to discuss our recommendations and develop an action plan. Those involved in the work can best set priorities and assess the feasibility of our recommendations for the specific situation at the building.

Our recommendations are based on an approach known as the hierarchy of controls (Appendix A). This approach groups actions by their likely effectiveness in reducing or removing hazards. In most cases, the preferred approach is to eliminate hazardous materials or processes and install engineering controls to reduce exposure or shield employees. Until such controls are in place, or if they are not effective or feasible, administrative measures and personal protective equipment may be needed.

\section{Elimination and Substitution}

Eliminating or substituting hazardous processes or materials reduces hazards and protects employees more effectively than other approaches. Prevention through design, considering elimination or substitution when designing or developing a project, reduces the need for additional controls in the future.

1. Work with the NYCEDC and the helipad to help reduce or eliminate the external exhaust sources from the helicopters. This approach could include altering flight paths so that exhaust from the helicopters is not blowing toward the building or reducing the number of idling helicopters on the pad, which would likely decrease the frequency of symptoms reported.

\section{Engineering Controls}

Engineering controls reduce employees' exposures by removing the hazard from the process or by placing a barrier between the hazard and the employee. Engineering controls protect employees effectively without placing primary responsibility of implementation on the employee.

1. Contact an HVAC firm with experience in large HVAC system test and balance to:

a. complete a testing and balancing of the ventilation system that serves the employer spaces,

b. verify that sufficient outdoor air is supplied in accordance with ASHRAE 62.1-2016, and

c. verify that ASHRAE 55-2013 thermal comfort guidelines are met.

2. Stop using charcoal filters in this building's AHU because they are not likely to be effective in removing the odors. If, however, a decision is made to keep the charcoal filters, install them behind the particulate air filters and replace them according to the manufacturer's schedule.

3. Move the laser printers and other objects so that they do not block peripheral fan-coil units. Unblocking the units will help ensure that those ventilation systems are working as designed. 


\section{Administrative Controls}

The term administrative controls refers to employer-dictated work practices and policies to reduce or prevent hazardous exposures. Their effectiveness depends on employer commitment and employee acceptance. Regular monitoring and reinforcement are necessary to ensure that policies and procedures are followed consistently.

1. Encourage employees with health concerns to seek evaluation and care from a physician who is residency trained and board certified in occupational medicine and is familiar with the types of exposures employees may have had and their health effects. You can locate these occupational medicine physicians through a variety of sources, including the Association of Occupational and Environmental Clinics at http://www.aoec.org, and the American College of Occupational and Environmental Medicine at http://www.acoem.org.

2. Test the diesel generators on the roof of the north building only during the weekend to ensure that no diesel emissions will enter the building from these generators during heavily occupied hours.

3. Ensure that any fuel located in the building is properly stored and contained, and that regular inspections occur to promptly remediate any leaks or spills so that fuel odors do not reach the HVAC system.

4. Improve communication between the employer, union representatives, employees, and the building owner regarding responses to employee safety and health concerns. A member of the safety management team should communicate directly with employees who report health and safety concerns to inform them of current issues with the building and plans or efforts to address those issues. In addition, the employer and building owner should work together and promptly respond to reported health and safety concerns.

5. Ensure that employees know a formal procedure is in place to report and document concerns. Make sure employees can submit a report confidentially. Document and communicate building improvements or changes in policies to all employees.

6. Ensure the existing health and safety committee includes employee, union, facility, and employer representatives to encourage effective communication and problem solving about IEQ concerns [Occupational Safety and Health Administration (OSHA) standard 1960.40; OSHA 2011]. Such a committee can be effective in improving employee perceptions of the employer's efforts to address issues and respond to complaints/ concerns and will increase employee involvement in identifying and mitigating employee safety and health concerns. An example of guidelines and suggestions for developing an effective health and safety committee can be found at https:/pantherfile.uwm.edu/groups/sa/usa/public/Safety/safcomm.pdf.

7. Implement an IEQ management program. Select an IEQ manager or administrator with clearly defined responsibilities, authority, and resources to lead the program. This individual should have a good understanding of the building's structure and function and should be able to communicate effectively with employees. Include an employee representative in the IEQ management program to assist with communication. Refer to 
the NIOSH/U.S. EPA document, "Building Air Quality: A Guide for Building Owners and Facility Managers" for guidance. This document is available at http://www.cdc.gov/niosh/pdfs/iaq.pdf. A companion NIOSH/EPA guide, "Building Air Quality Action Plan," discusses how to develop and assess an IEQ management program and is available at http:/www.cdc.gov/niosh/docs/98-123/pdfs/98-123.pdf. Although no comprehensive regulatory standards specific to IEQ have been established, guidelines have been developed by organizations and agencies, including ASHRAE, NIOSH, and EPA. These resources are available from the NIOSH Indoor Environmental Quality topic page at http://www.cdc.gov/niosh/topics/indoorenv/.

8. Compare the building emergency diesel generator usage logs to the complaint database recorded by the tenant to see if generator usage corresponds with some of the fuel odor complaints.

9. Evaluate ongoing illness and injury data and worker absenteeism records by floor and department to identify when and where employee complaints are more frequent. This may serve as an additional source of information about odors and potential IEQ problems.

10. Relocate employees who are very sensitive to the fuel odor incidents to an area of the building that is not as heavily impacted by these incidents.

11. Implement a fragrance-free policy. The American Lung Association provides resources for developing a policy at http://action.lung.org/site/DocServer/fragrance-free-workplace.pdf. 


\section{Appendix A: Occupational Exposure Limits and Health Effects}

NIOSH investigators refer to mandatory (legally enforceable) and recommended OELs for chemical, physical, and biological agents when evaluating workplace hazards. OELs have been developed by federal agencies and safety and health organizations to prevent adverse health effects from workplace exposures. Generally, OELs suggest levels of exposure that most employees may be exposed to for up to 10 hours per day, 40 hours per week, for a working lifetime, without experiencing adverse health effects. However, not all employees will be protected if their exposures are maintained below these levels. Some may have adverse health effects because of individual susceptibility, a pre-existing medical condition, or a hypersensitivity (allergy). In addition, some hazardous substances act in combination with other exposures, with the general environment, or with medications or personal habits of the employee to produce adverse health effects. Most OELs address airborne exposures, but some substances can be absorbed directly through the skin and mucous membranes.

Most OELs are expressed as a time-weighted average (TWA) exposure. A TWA refers to the average exposure during a normal 8- to 10-hour workday. Some chemical substances and physical agents have recommended short-term exposure limits (STEL) or ceiling values. Unless otherwise noted, the STEL is a 15-minute TWA exposure. It should not be exceeded at any time during a workday. The ceiling limit should not be exceeded at any time.

In the United States, OELs have been established by federal agencies, professional organizations, state and local governments, and other entities. Some OELs are legally enforceable limits; others are recommendations.

- The U.S. Department of Labor OSHA permissible exposure limit (PELs) (29 CFR 1910 [general industry]; 29 CFR 1926 [construction industry]; and 29 CFR 1917 [maritime industry]) are legal limits. These limits are enforceable in workplaces covered under the Occupational Safety and Health Act of 1970.

- NIOSH recommended exposure limits are recommendations based on a critical review of the scientific and technical information and the adequacy of methods to identify and control the hazard. NIOSH recommended exposure limits are published in the NIOSH Pocket Guide to Chemical Hazards [NIOSH 2010]. NIOSH also recommends risk management practices (e.g., engineering controls, safe work practices, employee education/training, personal protective equipment, and exposure and medical monitoring) to minimize the risk of exposure and adverse health effects.

- Another set of OELs commonly used and cited in the United States is the ACGIH TLVs. The TLVs are developed by committee members of this professional organization from a review of the published, peer-reviewed literature. TLVs are not consensus standards. They are considered voluntary exposure guidelines for use by industrial hygienists and others trained in this discipline "to assist in the control of health hazards" [ACGIH 2017]. 
Outside the United States, OELs have been established by various agencies and organizations and include legal and recommended limits. The Institut für Arbeitsschutz der Deutschen Gesetzlichen Unfallversicherung (Institute for Occupational Safety and Health of the German Social Accident Insurance) maintains a database of international OELs from European Union member states, Canada (Québec), Japan, Switzerland, and the United States. The database, available at http://www.dguv.de/ifa/GESTIS/GESTIS-Internationale-Grenzwerte-fürchemische-Substanzen-limit-values-for-chemical-agents/index-2.jsp, contains international limits for more than 2,000 hazardous substances and is updated periodically.

OSHA requires an employer to furnish employees a place of employment free from recognized hazards that cause or are likely to cause death or serious physical harm [Occupational Safety and Health Act of 1970 (Public Law 91-596, sec. 5(a)(1))]. This is true in the absence of a specific OEL. It also is important to keep in mind that OELs may not reflect current health-based information.

When multiple OELs exist for a substance or agent, NIOSH investigators generally encourage employers to use the lowest OEL when making risk assessment and risk management decisions. NIOSH investigators also encourage use of the hierarchy of controls approach to eliminate or minimize workplace hazards. This includes, in order of preference, the use of (1) substitution or elimination of the hazardous agent, (2) engineering controls (e.g., local exhaust ventilation, process enclosure, dilution ventilation), (3) administrative controls (e.g., limiting time of exposure, employee training, work practice changes, medical surveillance), and (4) personal protective equipment (e.g., respiratory protection, gloves, eye protection, hearing protection). Control banding, a qualitative risk assessment and risk management tool, is a complementary approach to protecting employee health. Control banding focuses on how broad categories of risk should be managed. Information on control banding is available at http://www.cdc.gov/niosh/topics/ctrlbanding/. This approach can be applied in situations where OELs have not been established or can be used to supplement existing OELs. 


\section{References}

ACGIH [2017]. 2017 TLVs ${ }^{\circledR}$ and BEIs ${ }^{\circledR}:$ threshold limit values for chemical substances and physical agents and biological exposure indices. Cincinnati, OH: American Conference of Governmental Industrial Hygienists.

ANSI/ASHRAE [2013]. Thermal environmental conditions for human occupancy. American National Standards Institute/ASHRAE standard 55-2013. Atlanta, GA: ASHRAE.

ANSI/ASHRAE [2016]. Ventilation for acceptable indoor air quality. American National Standards Institute/ASHRAE Standard 62.1-2016. Atlanta, GA: ASHRAE.

Apte MG, Daisey JM [1999]. VOCs and sick building syndrome: application of a new statistical approach for SBS research to US EPA BASE study data. Proceedings of Indoor Air 99, the 8th International Conference on Indoor Air and Climate, Edinburgh, Scotland, August 8-13, Vol.1, pp.117-122, https://eta.lbl.gov/sites/all/files/publications/42698.pdf.

Beach JR, Raven J, Ingram C, Bailey M, Johns D, Walters EH, Abramson M [1997]. The effects on asthmatics of exposure to a conventional water-based volatile organic compoundfree paint. Eur Respir J 10(3):563-566.

Benepe A, Birnbaum M [2016]. A plague of helicopters is ruining New York, http://www.nytimes.com/2016/01/31/opinion/sunday/a-plague-of-helicopters-is-ruining-newyork.html? $\mathrm{r}=0$.

CFR. Code of Federal Regulations. Washington, DC: U.S. Government Printing Office, Office of the Federal Register.

Claeson A, Liden E, Nordin M, Nordin S [2013]. The role of perceived pollution and health risk perception in annoyance and health symptoms: a population based study of odorous air pollution. Int Arch Ocup Environ Health 86(3):367-374, https://dx.doi.org/10.1007/s00420-012-0770-8.

Daisey JM, Hodgson AT, Fisk WJ, Mendell MJ, Brinke JT [1994]. Volatile organic compounds in twelve California office buildings: classes, concentrations and sources. Atmos Environ 28(22):3557-3562, http://dx.doi.org/10.1016/1352-2310(94)00200-5.

EPA [2017]. Fundamentals of indoor air quality in buildings, https://www.epa.gov/indoor-air-quality-iaq/fundamentals-indoor-air-quality-buildings.

EPA [2012]. The inside story: a guide to indoor air quality, http://www.epa.gov/iaq/pubs/insidestory.html.

HEI [2010]. HEI panel on the health effects of traffic-related air pollution. Traffic-related air pollution: a critical review of the literature on emissions, exposure, and health effects. HEI special report 17. Health Effects Institute, Boston, MA, https://www.healtheffects.org/publication/traffic-related-air-pollution-critical-reviewliterature-emissions-exposure-and-health. 
Hodgson AT, Levin H [2003]. Volatile organic compounds in indoor air: a review of concentrations measured in North America since 1990. LBNL Report 51715. Berkeley, CA: Lawrence Berkeley National Laboratory, https://www.researchgate.net/profile/Hal_Levin2/publication/228714997_Volatile_Organic Compounds in_Indoor_Air_A Review of Concentrations_Measured in North_America Since 1990 LBNL-51715/links/0deec51564a2f06c52000000.pdf.

Jaén C, Dalton P [2014]. Asthma and odors: the role of risk perception in asthma exacerbation. J Psychosom Res 77(1):302-308, https://dx.doi.org/10.1016/j.jpsychores.2014.07.002.

Kain J, Jex S [2010]. Karasek's job demands-control model: a summary of current issues and recommendations for future research. In: Perrewe PL, Ganster DC, eds. Research in occupational stress and well-being. Vol. 8: New developments in theoretical and conceptual approaches to job stress. Bingley, UK: Emerald Books, pp. 237-268.

Manual J [2013]. The long road to recovery: environmental health impacts of Hurricane Sandy. Environ Health Perspect 121(5):A152-A159, https://dx.doi.org/10.1289/ehp.121-a152.

NIOSH [2010]. NIOSH pocket guide to chemical hazards. Cincinnati, OH: U.S. Department of Health and Human Services, Centers for Disease Control and Prevention, National Institute for Occupational Safety and Health, DHHS (NIOSH) Publication No. 2010-168c, http://www.cdc.gov/niosh/npg/.

NYCEDC [2016]. New York City Economic Development Corporation and Helicopter Tourism \& Jobs Council announce new measures to reduce helicopter noise and impacts across New York City, http://www.nycedc.com/press-release/nycedc-and-helicopter-tourism-jobs-council-announcenew-measures-reduce-helicopter.

OSHA [2011]. Occupational Safety and Health Committees, OSHA standard 1960.40, http://www.osha.gov/pls/oshaweb/owadisp.show document?p table=STANDARDS\&p id=11289.

Petersen RL, Ratcliff MA, Wisner C [1990]. Helicopter fume entrainment evaluation. Eighty-Third Annual Meeting and Exhibition of the Air and Waste Management Association, Number 90-149.3, Pittsburgh, PA.

Saker Aviation Services [2015]. Downtown Manhattan heliport: location, http://www.downtownmanhattanheliport.com/location.html.

Shusterman [2002]. Review of upper airway, including olfaction, as mediator of symptoms. Environ Health Perspect 110(Suppl 4):649-653.

Sundell J, Levin H, Nazaroff WW, Cain WS, Fisk WJ, Grimrud DT, Gyntelberg F, Li Y, Persily AK, Pickering AC, Samet JM, Spengler JD, Taylor ST, Weschler CJ [2011]. Ventilation rates and health: multidisciplinary review of the scientific literature. Indoor Air 21(3):191-204, https://dx.doi.org/10.1111/j.1600-0668.2010.00703.x. 
Tietjen GE, Khubchandani J, Ghosh S, Bhattacharjee S, Kleinfelder J [2012]. Headache symptoms and indoor environmental parameters: results from the EPA BASE study. Ann Indian Acad Neurol 15(1):S95-S99, https://dx.doi.org/10.4103/0972-2327.100029.

Tucker WG [2000]. An overview of PM2.5 sources and control strategies. Fuel Processing Tech 65(1):379-392, http://dx.doi.org/10.1016/S0378-3820(99)00105-8.

Wark K, Warner CF [1981]. Air pollution: its origin and control, 2nd ed. New York: Harper \& Row Publishers.

WHO [2009]. WHO guidelines for indoor air quality: dampness and mold. Copenhagen, Denmark: World Health Organization Regional Office for Europe, ISBN 978928904168 3, http://www.euro.who.int/_ data/assets/pdf_file/0017/43325/E92645.pdf.

Wolkoff P, Kjaergaard SK [2007]. The dichotomy of relative humidity on indoor air quality. Environ Int 33:850-857, https://dx.doi.org/10.1016/j.envint.2007.04.004. 
Keywords: North American Industry Classification System 926120 (Regulation and Administration of Transportation Programs), New York, Indoor Environmental Quality, IEQ, Ventilation, Helicopters, Helipad, Odors, Exhaust, Respiratory Symptoms, Sinus Congestion, Eye, Nose, and Throat Irritation, Fuel 
This page left intentionally blank 
The Health Hazard Evaluation Program investigates possible health hazards in the workplace under the authority of the Occupational Safety and Health Act of 1970 (29 U.S.C. § 669(a) (6)). The Health Hazard Evaluation Program also provides, upon request, technical assistance to federal, state, and local agencies to investigate occupational health hazards and to prevent occupational disease or injury. Regulations guiding the Program can be found in Title 42, Code of Federal Regulations, Part 85; Requests for Health Hazard Evaluations (42 CFR Part 85).

\section{Disclaimer}

The recommendations in this report are made on the basis of the findings at the workplace evaluated and may not be applicable to other workplaces.

Mention of any company or product in this report does not constitute endorsement by NIOSH.

Citations to Web sites external to NIOSH do not constitute NIOSH endorsement of the sponsoring organizations or their programs or products. NIOSH is not responsible for the content of these Web sites. All Web addresses referenced in this document were accessible as of the publication date.

\section{Acknowledgments}

Desktop Publisher: Shawna Watts

Editor: Ellen Galloway

Logistics: Donnie Booher, Kevin Moore

Medical Field Assistance: Rini Mathew

\section{Availability of Report}

Copies of this report have been sent to the employer and employees at the facility. The state and local health department and the Occupational Safety and Health Administration Regional Office have also received a copy. This report is not copyrighted and may be freely reproduced.

\section{Recommended citation for this report:}

NIOSH [2017]. Evaluation of indoor environmental quality and health concerns in a commercial office building near a helipad. By Zwack LM, West CA, Burton NC, Garcia A. Cincinnati, OH: U.S. Department of Health and Human Services, Centers for Disease Control and Prevention, National Institute for Occupational Safety and Health, NIOSH Health Hazard Evaluation Report 2015-0037-3283, http://www.cdc.gov/niosh/hhe/reports/pdfs/2015-0037-3283.pdf. 
Delivering on the Nation's promise:

Safety and health at work for all people through research and prevention

To receive NIOSH documents or more information about occupational safety and health topics, please contact NIOSH:

Telephone: 1-800-CDC-INFO (1-800-232-4636)

TTY: 1-888-232-6348

CDC INFO: www.cdc.gov/info

or visit the NIOSH Web site at www.cdc.gov/niosh

For a monthly update on news at $\mathrm{NIOSH}$, subscribe to $\mathrm{NIOSH}$ eNews by visiting www.cdc.gov/niosh/eNews. 